\title{
Biology, environment, and culture: From animal communication to human language and cognition*
}

\author{
T. V. Chernigovskaya \\ St. Petersburg State University, \\ 7-9, Universitetskaya nab., St. Petersburg, 199034, Russian Federation
}

For citation: Chernigovskaya T. V. Biology, environment, and culture: From animal communication to human language and cognition. Vestnik of Saint Petersburg University. Philosophy and Conflict Studies, 2020, vol.36, issue 1, pp. 157-170. https://doi.org/10.21638/spbu17.2020.113

Contradictions in interpreting data from different scientific domains exploring anthopogenesis and language evolution will remain unsolved without a convergent approach and mutually acceptable multidisciplinary language. The article addresses the question of specific features of mental functions and language in humans as compared to other species. The main hypotheses of human evolution and their language are discussed. Cognitive capacities of animals and their communication signals are addressed, as are the basic principles of brain functions and bio-evolutionary mechanisms that underlie the complexity of human behavior and language evolution. Human language is a species' specific brain ability, promoting not only complex communication signals, but also mentality itself. Language has basic universal rules, possibly caused by brain networks per se. It is hierarchically organized within the levels of lexicon, grammar (morphology, syntax, semantics and phonology) and pragmatics. The functions and their brain mechanisms are currently discussed either within the localizationistic modular approach, or within holistic views. The main discussions are between scholars exploring universal inborn grammar, and those preferring connectionism based on neuronal net learning, frequency factors, etc. One of the features of language in contrast to other communication systems is its principal ambiguity on many linguistic levels, context being a crucial aspect.

Keywords: evolution of language and mind, communication systems in animals, human origin and evolution, information processing under ambiguity.

Human cognition came after human anatomy. Didit? For decadesthe problem has beendiscussed as to how language is organized in the brain - both in each of its parts and in the neuronal network as a whole; how the activity of neuronal assemblies is redistributed; how and why new functional connections are formed; how this is affected by information coming from outside and by genetic factors underlying the human language competence. Linguists are increasingly involved in such discussions and make attempts, using theoretical basis and specially designed experiments, as well as the data obtained by neurosciences, to reveal the structure of the human language or, to be more precise, its universal, basic properties that distinguish it from all known communicative systems but basic for national languages. Geneticists have also been involved in the gen-

* The study was funded by RFBR according to the research project No. 18-00-0646 (18-00-00640).

(C) Санкт-Петербургский государственный университет, 2020 
eral discussion because of the search for the 'language gene.' The discussion on the origin of language is activated again and, hence, of the evolution of Homo loquens. There has been increasing progress in the development of the multidisciplinary approach to language origins that was caused by the progress in such far-standing domains as historical linguistics and archeology on the one hand, and primatology, anthropology, anatomy, and neurosciences on the other. Not only cross-disciplinary borrowing of data provides further knowledge, but theoretical implications and analogies are no less productive. The contribution of paleo-anthropological research to the problem of language evolution is well-acknowledged. There is also a growing interest in bio-evolutionary perspectives to the mechanisms that underlie the complexity of human behavior and language evolution. The main universal features of human language outlined are formulated (likegraduality, structural differentiation, and adaptivity). Many aspects of language functions' development are intensively studied, among them the conceptualization of thought, embodiment, metaphoric thinking, the special role of poetry as a cognitive tool, mental grammar, and lexical and syntactic ambiguity, etc. [1-22].

Being a universal code language still has significant cross-linguistic variations: e.g. languages differ in the number of syllables they have with a large variation in the amount of information per syllable. Still, all natural language sefficiently encode and transmit information. Recent findings of Coupé et al. [23] reveal the feedback loops between languages' structural properties and speakers' neurocognition under communicative pressures. These variationsare of very high levels across the 6000 or so languages. For example, linguistic differences between Japanese and English lead to a ratio of 1:11 in their number of distinct syllables [24]. Neural oscillations carry speech rhythm through to comprehension, and it coincides with the syllabic nature of a language [25-27].

One of the puzzles of language is its principal ambiguity on many linguistic levels, the context being a crucial element. Speech recognition consists of perception, processing, and interpretation of linguistic units. A speaker faces a choice from several possible options, soin put is always ambiguous. Considering the use of different strategies in processing ambiguous incentives, one can check which factors are key for the system, on what principles it relies upon, and various models describing how it functions can be tested. How does linguistic processing occur under ambiguity and how is one of the options chosen? All the meanings of the ambiguous stimulus (lexical, semantic or referential) are activated immediately in speech processing, and only in the later stages is one selected. There are no observer-independent properties, neither in the world, nor in verbal language. Wittgenstein introduces a metaphor of a carpet: every reader draws out his own thread from it... As far as we know, no animal communication system sreveal this property. There are various models of ambiguity resolution that describe how the selection of a meaning occurs [28-29]. However, it is still unclear, how selected meaning remains table and what factors lead to its transformation.

Discussions on Nature vs. Nurture mechanisms of the human language develop according to a domain: biologists and psychologists mainly stress the environment as having a predominant role while linguists (the more formal the more so) emphasize specific innate mechanisms, whereby a genetically determined ability to acquire a special code human language, with its specific and unique structure - is postulated. Studies of the origin of language are of increasing interest to a wide range of disciplines, including not 
only linguistics, but also anthropology, archeology, cognitive sciences, psychology, evolutionary theory, biochemistry, genetics, paleo-geography, and, finally, neuroscience.

There are increasingly active searches for (and findings of) specifically human genes (FOXP2, HAR1F, ASPM...). People seek their roots. Investigators, not only Darwin, have long sought and indeed found exotic 'subjects': it has been proposed that the genus Homo should be subdivided into Homo sapiens and Homo troglodytes (human-animals) [30], a creature with a "human body, monkey's mind" (corpore homo, intellectu simian) has been reconstructed, i.e., Mikrocephalenor Affen-Menschen [31], Pithecanthropus alalus [32], and others. All this is the prehistory of current arguments regarding the status of humans on the evolutionary ladder and what separates us so fundamentally from the rest of the living world populating our planet. Ultimately, our extraordinarily complex and powerful brain supports language as a means for thought and communication, the ability to construct models of the world and to identify its laws, and, finally, the ability for selfcomprehension.

How could a brain conferring reason on humans have arisen? At least two possible scenarios are considered. The first scenario holds that this occurred as a result of a series of genetic changes leading to some kind of "explosion." This would be a series of mutations, by some mechanism altering the properties of the nervous system and having evolutionary adaptive value. Other changes could have been superimposed on this "explosive mutation," and what we see today is not one "main" mutation (which is absurd), but thousands, which occurred afterwards. However, there is another serious scenario, according to which everything started with some changes in adaptability, or brain plasticity which, finding itself in an altered evolutionary niche, started to exploit new potentials: genetic variations making this the preferred direction of development started to accumulate. Having accumulated, these variations then led to the formation of the human brain in its current form. This scenario excludes the existence of an initial "key gene" imparting a blow to the system. Evolution was aimed at the growth of the ability to produce categorical descriptions of the world [33-35].

On the other hand, recent studies have demonstrated that about $22 \%$ of all species' differences were genetically fixed at the "moments" of sudden changes, i.e., development can occur entirely in "jumps," as also indicated by the opposing viewpoints of gradual and punctuated evolutionary scenarios [36].

If the first scenario can be termed the "genetic," then the second is the epigenetic; besides, many geneticists and evolutionary scholars are coming to regard the latter as the fundamental scenario. One of the world's first to develop these theories was Shmal'gauzen [37], who took the view that evolution started not with changes in the genotype, but, conversely, with changes in the phenotype, which were gradually fixed and formed as changes in the genotype.

Other views of evolution also seem plausible. In this regard we can recall Fodor's paper Why pigs don't have wings [34]. Fodor accords with the view that there are in fact no serious alternatives to Darwin's phylogenetic concept, but he is skeptical with respect to the idea of natural selection and, thus, adaptation, emphasizing the lack of a need for a link between them; he holds that the lack of grounds for the role of adaptation does not harm the concept of phylogenesis. His main claim regarding natural selection is that it is logically inconsistent and hence unverifiable, what he calls a methodological truism. Pigs lack wings because there's no place on pigs to put them, concludes Fodor. We have language, be- 
cause we have a place to put it. This is not because it makes life more convenient and survival more effective in the competitive evolutionary struggle, because that would require us to explain why thousands of biological species without such a developed mechanism have excellent survival. Pigs with wings have never been found and described anywhere for natural selection to reject them from nature.

In this regard, important ideas were formulated by Deacon [38], who suggested that language "occupied" the brain and adapted to it to a much greater extent than the brain evolved towards language. The brain and language co-evolved, though the major burden of adaptation, according to Deacon, was borne by language. Thus, children are born with a brain ready for syntactic procedures because of the development of language towards the most likely characteristics, and becomes genetically fixed.

Evolution made a jump leading to the acquisition by the brain of the ability to count and to use recursive rules and mental representations, thus creating the conditions for thought and language in the human sense. The new "grammar machine," in Jackendoff's term [21], allowed language structures to grow for organization (thinking) and transmission (communication) of all complex concepts. And perhaps, conversely, I do not believe that we are ready to establish the true cause-effect relationships. Fodor formulated this as A theory of causation and it is exactly what a theory of natural selection is not.

The search for areas of DNA which would have to undergo significant changes over a million years and now distinguish us from chimpanzees identified 49 areas in which the rates of change were significantly greater than the genome average, in some cases by factors as large as 70! The HAR1 gene was identified; this encodes a small unit containing 118 differences between humans and chimpanzees (for comparison there are just two such differences between chimpanzees and birds) [39]. This is a gene active in the cerebral cortex from the seventh to the 19th weeks of fetal development, when the upper, evolutionarily recent, layers of the cortex which distinguish the human brain from the brains of other primates, develop. Biological and specifically genetic aspects of language evolution or even revolution is currently discussed more and more energetically [39-41].

It is not controversial that discussion on specifically human genes supporting our evolution and the phenomenal rate of the recent development of civilization must be conducted with great accuracy and without any expectation of sensations. Many years of careful work and consideration of the results are needed before we can (if we can) provide a confident description of the genetic mechanisms playing key roles in our specific biological evolution. We should not flatter ourselves with the idea of a long-awaited "reason gene," as there are at least ten candidates for this special role... It is now clear that cognitive processes themselves affect genetic processes, which forces us to view much from a new perspective.

Anthropological estimates and radiometric measurements of the age of Homo sapiens, supported by molecular genetic data, indicate that the entire current population of humans dates back genetically to a relatively small group located in Africa to the south of the Sahara some 100-150,000 years ago. The mitochondrial DNA haplogroups of the Near East and Europe have been found to be quite close. The earliest European haplogroup has aNear East origin and it propagated into Europe some 50,000 years ago. The probability that there were multiple centers for the origination of Homo sapiens is regarded as very small $[42 ; 43]$. The mono- or multigenesis of human language has long been the subject 
of discussion, with a clear predominance of the monogenesis view (existence of a "prototower" language) [44].

Modern humans had, even at their early stages, a cognitive system allowing them to conceptualize space and time in symbolic form. This is entirely consistent with later views of the grammar explosion supporting the formation of the mental functions required for syntactic language, planning of logical operations, inventing games based on rules of convention, and supporting imaginative and musical creative abilities [8; 40].There is evidence that at the early stages, modern humans had cognitive flexibility, syntactic language, and the ability for abstract thought. This conferred evolutionary and adaptive advantages promoting increases in population numbers, which led to the wide settlement of people in tropical Africa to the monsoon areas of the Near East. An adaptation model of the social setting with ritualized social functions developed at the early stages of settlement. It is important to stress still that there are crucial differences between humans and any nonhuman species in terms of syntactic capabilities $[15 ; 16 ; 45]$.

Darwin noted that the difference between us and other species, particularly closely related species, is in degree rather than quality: the fundamental principles must remain the same. Shmal'gauzen wrote that all biological systems are characterized by the ability to regulate themselves; three main self-regulatory factors in ontogenesis should be noted:

1) development in accord with a genetic program; 2) development depending on the actions of the environment (for example, the negative influences of sensory deprivation lead to underdevelopment of the brain, and the lack of a speech environment leads to underdevelopment of language, etc.); 3) intrinsic conscious self-regulation - a property which increases with increases in the ranking of biological objects on the evolutionary ladder as a result of the increasing role of individual rather than group behavior. Increases in independence from the environment are a characteristic of evolution. And finally, this increasing independence is already apparent within a community of people as humanity as a whole develops and separate individuals advance as a result of the assiduous work of the individual himself and the people who nurture and cultivate him. The organism's external behavior is determined by a mechanism with a complex organization formed by structures whose real functions depend on experience in a given environment. Some of the common principles of evolution (as we now understand them) describe a surprisingly different process as the evolution of living systems and natural and artificial languages [46; 47].

The flexibility of behavior and the breadth of adaptive capacity in most of the species from invertebrates to higher primates are striking. In all cases this applies to memory, the ability to alter behavior depending on the situation, to read the language of adversaries, victims, and fellows, to construct rules, and therefore to compute. Evolution does not hurry! The question of "who wins" is meaningless - answers to this question tend to be unpalatable: "viruses," or "insects." Overall, humanity, if it is going to continue in the same vein, could well destroy itself and all its achievements - the Uffizi Gallery, the music of Mozart, and the glories of mathematical and philosophical thought. And the survivors will be the simplest organisms - for example, those living on the ocean floor, those living at temperatures of $+400^{\circ} \mathrm{C}$, and those surviving without photosynthesis...

However, no one doubts the very important role of humans on the planet or the absolutely special role of specific semiosis and language in our development. Semiotic behavior is part of life in all organisms, even in invertebrates. When we speak of highly 
developed species, the meta-cognitive capacity and ability for meta-representation are discussed and animals (possibly excepting primates and dolphins) are regarded as lacking the concept of "self" and the capacity for making mental "journeys through time," as this requires symbolic language able to represent future events and tasks, the ability to go beyond the limits of one's own world and the self as its center (if not to say its main content). Representation of individuals not in sight requires words, representation of appropriate behavior requires conventions... Discussions of the ability to construct a theory of mind are related to this, and it was recently believed that is this lacking not only in animals, but also in young children aged 3-4 years [5]. Nonetheless, in contrast to robots, which actas "zombies," animals have "subjective reality" - a "phenomenal experience," or "qualia." And although the questions "why subjective reality?" and "why did this arise during biological evolution?" remain extremely difficult, we cannot avoid them when analyzing the features of mental functions and language in animals and humans; this also applies to the question of the appearance and essence of semiosis in general.

Chalmers [48] emphasized that explanation of subjective experience is the main question in the problem of consciousness. We can give functional explanations of information processes linked with perception, thought, and behavior, but we still do not understand why these information processes are accompanied by subjective experience. He formulated the "key question in the problem of consciousness" as follows: "Why do all these information processes not 'run in the dark' independently of any inner feeling?" It may support integrity, autonomy, selfhood, understanding of the limits of "I," i.e., again referring to Shmal'gauzen, an increasing independence from the environment and its "inhabitants."

It is also still difficult to give this definition not only for the reasons clearly expressed by Penrose [49] (consciousness cannot be explained by computation, as the living brain has the ability to understand, and this is a special non-computable ability based on analog procedures; some kind of an analog computer operating in the brain).

The increasingly multistep nature of operations which occurred during evolution allows us to go beyond the ongoing situation, to generalize experience, to develop the ability to perform delayed actions, to predict, and to construct models of the future. In higher animals, the complexity of information about information is much lesser than in ourselves, and they cannot probably be seen as having self-consciousness or free will, though as is now very clear, they are able to solve complex cognitive tasks, coping with uncertainty and ambiguity and making choices to achieve aims, which forces us to regard their mental activity in a less arrogant manner, though they still lack a semiosphere comparable to ours.

The discovery of the mirror system of the brain $[4 ; 50 ; 51]$ illustrated that these neural systems synthesize information reflecting not only external stimuli, evoked by the actions of other entities, but also our own responses and actions; they support links between the brain subsystems responsible for perception, memory, motivation, and motor activity; they map subjective-objective relationships; they form the mechanisms of self-identification. Mirror systems are also associated with the production and understanding of speech, and with orientation in complex social spaces. Rizzolatti and Arbib regarded language (production and perception) as a means of uniting cognitive, semantic, and phonological forms, relevant both for acoustical and sign language. Mirror neuron activity in zone F5 is interpreted as part of a code which has to be linked with neuron activity in some other part of the brain, thus forming an overall code indicating an object and /or subject. This hypothesis is of prime importance both for explaining the organization of language func- 
tions, particularly for linguistic differentiation of subject and object, and for learning in general, as it allows agence, patience and instrument to be linked.

These discoveries have been discussed not only by biologists, but also by psychologists, linguists, and philosophers, and have been regarded as the most important discoveries of the twentieth century in the evolution of complex behavior and the origin of language [6;7]. Studies of neurophysiological mechanisms of such complex processes as meta-representation and subjective reality are not yet sufficient or interpretable neither in animals nor humans, and there is little expectation of 'objective' studies of the structure and level of mental organization of other biological species: behavioral studies are only tools making the walls between $u s$ and them more transparent.

At numerous conferences concerning evolution of language and mind, discussions address current views of the sources and specifics of human language. To name some issues:

- The neuroanatomical substrate of human language formed two million years ago in Homo habilis [52].

- Some protolanguage arose about one million years ago in Homo erectus and already had specific features (an order of elements, verb arguments, grammar, etc.) $[2 ; 3]$.

- An acoustic language independent of the visual modality may have arisen in Africa as a result of mutation [53].

- The completeness of the formed syntactic language as a necessary condition for the exchange and transmission of symbolic information can be dated indirectly by comparison with abstract petroglyphic images dating to about 75,000 years ago [54].

- Artifacts found in caves in South Africa, along the Klasies river, provide evidence that at least 115,000 years ago people were able to think in symbols and speak [55].

- The acoustic signals of birds evolved into human singing $[15 ; 17 ; 56]$.

- Recursion in human language can be regarded as comparable with recursion in acoustic behavior in birds $[57 ; 58]$.

- Animals have been suggested to be capable of "phonology" $[23 ; 59 ; 60]$.

- Syntax, imitation, "citation", and mental representation. The ability of consciousness to reflect consciousness (minds within minds) $[1 ; 19 ; 24 ; 58 ; 61]$.

Finally, one of the cardinal discussions is one which is running for several years around articles by Hauser, Chomsky, and Fitch [18-20] on language properties which are specific versus those common to other species. The studies of Jackendoff and Pinker are extremely important in evaluating this question. Their main concept relates to the controversy with the supporters of generative grammar, for whom the center of language and its combinatorial possibilities are syntax and the recursive ability. Jackendoff [21] believes that his suggestion, which has proved very controversial, has better grounds: this is the concept of a parallel architecture in which phonology, syntax, the lexicon, and semantics are independent generative systems connected to each other via interfaces. This concept is much more consistent both with neuroscience data and the mental theory of semantics, and with the more likely (compared with a single mutation) hypotheses of the evolution of human language ability.

According to Jackendoff, meaning (rather than syntactic structures) must be the first generative component evoking the appearance and further development of language. The 
first stage was probably expressed by the symbolic use of very simple vocalizations without any kind of grammatical organization. At this stage, ultimately, there was no syntax, but there was already a paleolexicon reflecting primitive concepts. Primary syntax then started to appear, allowing differentiation, for example, of object from subject, marking this using the order of communicative components. It was only when expressive semantics and conventional rules relating semantics to phonology became sufficiently developed that syntactic structures appeared. This approach ultimately provides a much better route, compared with previous approaches, to integrating different areas of knowledge to construct a non-contradictory theory.

This position elicited strong criticism from adherents of the main generative paradigm, which places syntax in a privileged position and insists that language made a sudden rather than an evolving appearance. Thus, Bickerton finds no explanation for the fact that a gradually developing (as per Jackendoff) language would not produce any changes in other types of cognitive evolution, as if frozen for hundreds of thousands of years. He also sees no reason to supplement his formulation of two stages in the appearance of language: an asyntactic protolanguage and the syntax-based language of modern people.

The main formal differences between human language and the languages of other species are its openness and productivity, as well as its ability to use recursive rules. That is, our language is fundamentally differently constructed. Continuing the discussion of the specificity of communication systems and the features of the intellect, we must first provide a clear definition of the coordinates, to avoid the repeatedly encountered situation of, for example, analyzing the achievements of talking monkeys. Evolution has tested and continues to test different tools, and many of these coexist in space and time. Successful communication is not achieved solely because of successful language algorithms! Discussion of the well known fact that language serves not only communication, but also (some think mainly) thought, should not be excluded from the discussion. The co-evolution of different types of communication, with genetic reinforcement, is of significant importance.

A number of discouraging (if the discussion is not tendentious) examples of the "competence" of other biological species, not only primates or other mammals, but also birds, ants, and bees can be mentioned (e.g. [62]):

- The ability to perform interspecies communication. The ability to learn the language of another species, intercommunicate with it, mimicking. Understanding the language of others (even "words") which is advantageous.

- The ability to generalize signals: use of acoustic anxiety signals of similar frequencies by different species living in the same place. Imitation of signals of the other species, for example, on begging for food.

- The abilities to assess a situation quickly and effectively, to change roles, substitute strategies, even estimate the energy costs of efforts, to evaluate risk, and to perform multiway planning.

- High specialization and elegance of roles in society, regulation of relationships between social strata, assessment of place and the depth of understanding of own/ foreign depending on a multi-factorial space.

- Use different modalities by the same individuals: acoustic, chemical, and tactile.

- Different degrees of symbolic behavior (one of the highest is the dance language of bees). 
- Multiplicity of variants of social order not only in different species and groups, but within a single species, and selection of behavior requiring a significant computational load. Use of consummate guile to economize energy (food, home construction efforts): attacking, waiting, using foreign pheromones, dissimulation. Agreement to feed others in exchange for their services; 'slavery', 'cattle breeding, and 'farming' (milking aphids and cultivating fungi), understanding measures of the permissibility of actions, the rules for different members of a group.

- The ability to analyze a situation and select a means of conducting wars: chemical weapons, including those inducing panic ('mass hysteria'), when individuals start to annihilate each other while the attackers make off with the supplies and pupae which subsequently yield 'slaves' or food; 'kamikazes'; 'scouts' sometimes acting alone and sometimes in groups to undertake a particular strategic task; 'border guards' ensuring perimeter security in a single line or several, depending on the situation. How do they assess it? How do they negotiate? What is this 'distributed brain'?

Attempts to decipher the acoustic signals of animals, once discrete meaningful elements of the phoneme type have been extracted, have as yet been met with limited success, though studies of this nature are under way and the results give cause for thought: for example, in relation to the possibility that animals have "phonologies" [59] and, in the case of the European starling Sturnus vulgaris, recursive ability [63].

The signals of animals are taken to be purely emotional and utilitarian in meaning, though they can also have complex semantics (information about distance, topography, existence of male and female languages, different 'words' for different objects evoking fear, and generalized signals of the 'general danger' type). It should not, however, be forgotten that the formation of 'words' by animals took millions of years of genetic selection, while humans acquire a lexicon during individual ontogenesis and, unlike those in animals, the words of human languagesare ambiguous and have multiple meanings depending on a shifting context.

No less discouraging are the properties of human language seen in the language oftalking monkeys, which have been described in detail in [64]:

- Semanticity - the assimilation of the meaning of a defined object or action and using it in place of the action or manipulations with a subject.

- Signs of semantic syntax: similarto topic-commentin child language - in oneword and two-word orations.

- Productivity - the ability to create new statements about assimilated rules. (It is interesting to note that the sequence of elements can also change in the long cries of chimpanzees.)

- Transferability-naming of an object outside the field of vision, the transmission using only information signs regarding past and future events. Use of the lexicogramsnow andthen. (This is also seen in nature: cognitive maps of chimpanzees, planning routes and subsequent actions).

- Cultural continuity (knowledge is propagated by mechanisms other than genetics): the ability and desire to teach each other and children, with correction of errors, has always been regarded as a privilege of humans. The possibility of using American Sign Language to communicate with each other, not only with humans. 
- Recognition of the self in a mirror and in video films. Error-free employment of pronouns I, your, you, we, which is evidence of meta-representation ability.

- Abstract behavior - the skills of planning, predicting, and identifying final and intermediate aims. The skills of manipulating the environment. Reconstruction of the goals of others.

- The ability to take part in dialogs and exchange roles and ranks (see also [22]).

- Perception of oral human speech and its translation into a sign language.

Thus, we are a species with a high level of semiotic ability, capable of abstract thought, able to formulate concepts, to perform the recursive syntactic procedures which support the openness of grammatical and semantic systems, which are tightly linked with the ability to construct high-level models of the Theory of Mind and represent an important step in the evolution of cognitive capacities. The combination of phonemes to form syllables, of syllables to form words, of words to form phrases, etc. can be compared, for example, with the construction of complex motor acts from simpler components, though multistage motor acts do exist in primates while language acts do not.

Concepts of consciousness and Theory of Mind active use, planning one's actions accordingly, provide an enormous behavioral advantage (assuming we recognize the benefits of adaptive processes).It is, however, unclear how and why jumps (or developments) from the closed communication systems of animals to the open systems of humans occurred. The cognitive capacities of humans and the operant possibilities of language converge here. Extrapolations and especially syntactic procedures forming them require welldeveloped operative and long-term memory and a powerful brain to mediate them. It is important to note that Jackendoff and Pinker take the position of the slow development of systems preceding language on the basis of completely Darwinian adaptation, while Hauser, Chomsky, and Fitch prefer the revolutionary scenario, i.e., the appearance of language as a result of some event.

No less important is the question posed by Fodor: how language could give us an evolutionary advantage when it was not yet present... This question is complex and confusing and requires a multidisciplinary interpretation, the need for which has particularly been noted by V. Ivanov in Linguistics in the Third Millennium: Questions for the Future [65]: "If advances in knowledge of the humanities in the present century depend (as many have suggested) on combining progress in the natural sciences, especially biology, with data from the humanities which to date have received little study from this point of view, then neuro-linguistics and psycho-phonetics are areas in which progress has already started."

Thus, Homo loquens' characteristic feature is not the use of recursive rules in a narrow (syntactic) sense, but the openness of the system as a whole - not the gap between humans and other species. Rather it is the complexity of a system of some other order which arose for some reason (not necessary for some purpose) mediating not only language and semiosis, but reflection, phenomenal mind, and thus culture, allowing us to evolve further.

Not only the scenarios, but vectors of human evolution are of existential importance: the process continues - not only in the cultural sense, but also in the biological [14; 66-69]. 


\section{References}

1. Chomsky, N. (2002), New Horizons in the Study of Language and Mind, Cambridge University Press, Cambridge.

2. Bickerton, D. (2003), "Symbol and structure: a comprehensive framework for language evolution", Christiansen, H. and Kirby, S. (eds), Language Evolution: the States of the Art, Oxford University Press, New York, pp.77-93.

3. Bickerton, D. (2007), Language evolution: A brief guide for linguists, Lingua, vol. 11, no. 3, pp. 510526.

4. Arbib, M.A. (2005), From monkey-like action recognition to human language: An evolutionary framework for neurolinguistics, Behavioral and brain sciences, vol. 28, no. 2, pp. 105-124.

5. Givón, T. (2009), The Genesis of Syntactic Complexity, John Benjamins Publishing Company, Amsterdam, $366 \mathrm{p}$.

6. Chernigovskaya, T., (2007), "Language Origins and Theory of Mind. Combat pour les Langues du Monde", in Jocelyne Fernandez-Vest, M. M. (ed.), Fighting for the World's Languages. Hommage a Claude Hagege, Editions L'Harmattan, Collection Grammaire \& Cognition, Paris, pp. 105-114.

7. Chernigovskaya, T. (2009), From Communication Signals to Human Language and Thought: Evolution or Revolution?, Neuroscience and Behavioral Physiology, vol.39, no. 8, pp. 785-792.

8. Chernigovskaya, T. V. (2008), "What makes us human: why are there always recursive rules? (from the point of view of a linguist and biologist)", in Koshelev, A. D. and Chernigovskaya, T. V. (eds), Reasonable behavior and language. Communicative systems of animals and humans. The problem of the origin of the language, Iazyki slavianskoi kul'tury Publ., Moscow, pp.395-412. (In Russian)

9. Chernigovskaya, T. V. (2010), If the mirror looks in the mirror, what will it see there (on the issue of the evolution of language and consciousness), Cognitive studies, no. 4, pp.67-89. (In Russian)

10. Chernigovskaya, T.V. (2010), Brain and language: congenital modules or learning network? Vestnik RAN, vol. 80, no. 5-6, pp. 461-465.

11. Chernigovskaya, T. V. (2014), Before the experience acquired features... The human brain and the language that generated it, Logos, no. 1, pp. 79-96.

12. Chernigovskaya, T.V. (2015), "An Experimental Study of Language and Thinking in the $21^{\text {st }}$ Century: Traditions and Opportunities", in Alferov, Zh. I. (ed.), Promising areas for the development of science in St. Petersburg, SPbNC RAN Publ., St. Petersburg, pp.489-494. (In Russian)

13. Chernigovskaya, T. V. (2015), "Fuete, phoneme, formula, photon: languages of the brain and culture", in Tishkov, V.A. (ed.), Trudy otdeleniia istoriko-filologicheskikh nauk RAN, Nauka Publ., Moscow, pp. 177-187. (In Russian)

14. Kozincev, A. G. (2013), "Origin and early history of the species HOMO SAPIENS: new biological data”, in Molodin, V. V. and Shun'kov, M. V. (eds), Fundamental'nye problemy arkheologii, antropologii, etnografii Evrazii (k 70-letiiu akad. A. P. Derevianko), IAE SO RAN Publ., Novosibirsk, pp. 538-554. (In Russian)

15. Berwick, R. C., Okanoya, K., Beckers, G. J. and Bolhuis, J. J. (2011), Songs to syntax: the linguistics of birdsong, Trends in cognitive sciences, vol. 15, no. 3, pp. 113-121.

16. Berwick, R. C., Friederici, A. D., Chomsky, N. and Bolhuis J. J. (2013), Evolution, brain, and the nature of language, Trends in Cognitive Sciences, vol. 17, no. 2, pp. 89-98.

17. Bolhius, J. J. and Everaert, M. (2013), Birdsong, Speech, and Language. Exploring the Evolution of Mind and Brain, MIT Press, Cambridge, MA, $560 \mathrm{p}$.

18. Fitch, W.T. (2012), Evolutionary developmental biology and human language evolution: constraints on adaptation, Evolutionary biology, vol.39, no. 4, pp.613-637.

19. Fitch, W. T. (2017), Empirical approaches to the study of language evolution, Psychonomic Bulletin \& Review, vol. 24, no. 1, pp.3-33.

20. Hauser, M., Chomsky, N. and Fitch, W.T. (2002), The language faculty: What is it, who has it, and how did it evolve? Science, vol.29, no. 5598, pp. 1569-1579.

21. Jackendoff, R. (2002), Foundations of Language: Brain, Meaning, Grammar, Evolution, Oxford University Press, New York, 477 p.

22. Levinson, S.C. (2016), Turn-taking in human communication - origins and implications for language processing, Trends in cognitive sciences, vol.20, no. 1, pp. 6-14.

23. Coupé, C., Oh, Y.M., Dediu, D. and Pellegrino, F. (2019), Different languages, similar encoding efficiency: Comparable information rates across the human communicative niche, Science Advances, vol.5, no. 9, eaaw2594. 
24. Evans N., Levinson, S.C. (2009), The myth of language universals: Language diversity and its importance for cognitive science, Behavioral and brain sciences, vol. 32, no. 5, pp. 429-448.

25. Chernigovskaya, T. V. (1976), Dependence of perception of low-frequency amplitude modulation on age and training, Zhurnal evoliutsionnoi biokhimii i fiziologii, vol. 22, no. 4, pp. 387-389.

26. Chernigovskaya, T. (1977), Dependence of the perception of low-frequency amplitude modulation on age and training in man, Neuroscience and Behavioral Physiology, no. 4, pp. 341-343.

27. Assaneo, M. F. and Poeppel, D. (2018), The coupling between auditory and motor cortices is raterestricted: Evidence for an intrinsic speech-motor rhythm, Science advances, vol. 4, no. 2, eaao3842.

28. Chernigovskaya, T. V. (2013), Cheshire smile of Schrödinger cat: language and consciousness, Iazyki slavianskoi kul'tury Publ., Moscow, 448 p.(In Russian)

29. Chernigovskaya, T.V., Alekseeva, S.V., Dubasova, A.V., Petrova, T.E., Prokopenja, V.K. and Chernova, D.A. (2018), Schrödinger cat's view: recording eye movements in psycholinguistic research, St. Petersburg State University Press, St. Petersburg, 228 p. (In Russian)

30. Linnae, C. (1766-1768), Systema Naturae, Stockholm.

31. Vogt, K. (1867), Mikrocephalenoder Affen-Menschen, Braunschweig.

32. Häckel, E. (1899), Die Welträthsel. Gemeinvertstandliche Studienüber Monistische Philisophie, Strauss, Bonn, VIII, $473 \mathrm{p}$.

33. Fodor, J. (2001), The Mind Doesn't Work That Way: The Scope and Limits of Computational Psychology, MIT Press, Cambridge, $144 \mathrm{p}$.

34. Fodor, J. (2007), Why pigs don't have wings, London Review of Books, vol.29, no. 20, pp. 19-22.

35. Gardenfors, P. (2003), How Homo Became Sapiens: on the Evolution of Thinking, Oxford University Press, New York, 256 p.

36. Pagel, M., Venditti, C. and Meade, A. (2006), Large punctuational contribution of speciation to evolutionary divergence at the molecular level, Science, vol.314, no. 5796, pp. 119-121.

37. Shmal'gauzen, I.I. (1939), Ways and patterns of the evolutionary process, AN SSSR, $232 \mathrm{p}$. (In Russian)

38. Deacon, T. (2013), Incomplete Nature: How Mind Emerged from Matter, W. W. Norton \& Co. Ltd., New York, $627 \mathrm{p}$.

39. Pollard, K. S., Salama, S. R., Lambert, N., Lambot, M. A., Coppens, S., Pedersen, J. S., Katzman, S., King, B., Onodera, C., Siepel, A., Kern, A. D., Dehay, C., Igel, H., Ares, M., Vanderhaeghen, P. and Haussler, D. (2006), An RNA gene expressed during cortical development evolved rapidly in humans, Nature, vol. 443, no. 7108, pp. 149-150.

40. Kozincev, A. G. (2009), The evolutionary history of the species Homo sapiens in the light of new data from population genetics, Vestnik Moskovskogo universiteta. Ser. 23 (Antropologiia), no. 4, pp. 64-70.

41. Kozincev, A. G. (2013), Zoosemiotics and glottogenesis, Antropologicheskiiforum, no. 19, pp. 326359.

42. Bunak, V.V. (1980), The genus Homo, its origin and subsequent evolution, Nauka Publ., Moscow, 329 p. (In Russian)

43. Dolukhanov, P. M. (2007), "Archeology, radiocarbon and resettlement of Homo sapiens in northern Eurasia”, in Zaitseva, G. I. and Kul'kova, M. A. (eds), Radiouglerod v arkheologicheskikh I paleoekologicheskikh issledovaniiakh, Teza Publ., St. Petersburg, pp. 135-154. (In Russian)

44. Barulin, A. N. (2007), Towards the theory of glottogenesis, Kochergina, V. A. (ed.) Linguistic comparative studies in cultural and historical aspects: Proceedings of the V International Conference on comparative historical linguistics, Moscow University Press, Moscow, pp. 9-44. (In Russian)

45. MacWhinney, B. (2002), The gradual emergence of language,Givón, T. and Malle, B. F. (eds), The evolution of language out of prelanguage, John Benjamins Publishing Company, Amsterdam, Philadelphia, pp. 231-263.

46. Natochin, Ju. V., Menshutkin, V.V. and Chernigovskaya, T. V. (1992), General features of evolution in homeostatic and information systems, Zhurnal evoliutsionnoi biokhimii I fiziologii, vol.26, no.5, pp. 623-637.

47. Chernigovskaya, T., Natochin, Yu. and Menshutkin, V. (2000), Principles of evolution of natural and computer languages and of physiological systems, Bichakjian, B., Chernigovskaya, T., Kendon, A. and Moeller, A. (eds), Becoming Loquens - Bochum Publications in Evolutionary Cultural Semiotics, vol. 1, Peter Lang, Frankfurt am Main, Berlin, Bern, Bruxelles, New York, Oxford, Wien, pp. 211-236.

48. Chalmers, D.J. (2002), Philosophy of Mind: Classical and Contemporary Readings, Oxford University Press, New York, 688 p. 
49. Penrose, R. (1994), Shadows of the Mind: A Search for the Missing Science of Consciousness, Oxford University Press, New York, $474 \mathrm{p}$.

50. Rizzolatti, G. and Arbib, M. A. (1998), Language within our grasp, Trends in neurosciences, vol.21, no. 5, pp. 188-194.

51. Rizzolatti, G. and Craighero, L. (2004), The mirror-neuron system, Annual Review of Neuroscience, vol. 27, pp. 169-192.

52. Wilkins, W.K. and Wakefield, J.(1995), Brain evolution and neurolinguistic preconditions, Behavioral and Brain Sciences, vol. 18, pp. 161-182.

53. Corballis, M. C. (2003), From Hand to Mouth: The Origins of Language, Princeton University Press, Princeton, $272 \mathrm{p}$.

54. Henshilwood, C., d'Errico, F., Vanhaeren, M., Van Niekerk, K. and Jacobs, Z. (2004), Middle stone age shell beads from South Africa, Science, vol. 304, no. 5669, p. 404.

55. Wurz, S. (2002), Variability in the middle stone age lithic sequence, 115,000-60,000 years ago at Klasies river, South Africa, Journal of Archaeological Science, vol. 29, no. 9, pp. 1001-1015.

56. Masataka, N. (2007), Music, evolution and language, Developmental science, vol. 10, no. 1, pp. 3539.

57. Chi, Z., Wu, W., Haga, Z., Hatsopoulos, N. G. and Margoliash, D. (2007), Template-based spike pattern identification with linear convolution and dynamic time warping, Journal of Neurophysiology, vol. 97, no. 2, pp. 1221-1235.

58. Reuland, E. (2008), "Language - symbolization and beyond", in Knight, C. and Botha, R. (eds), The Prehistory of Language, Oxford University Press, New York, pp. 201-224.

59. Yip, M. (2006), "Is there such a thing as animal phonology?" in Bakovic, E., Junko, I. and McCarthy, J. J. (eds), Wondering at the Natural Fecundity of Things: Essays in Honor of Alan Prince, Linguists Research Center, University of California, Santa Cruz, pp.311-323.

60. Dediu, D. and Levinson, S. C. (2018), Neanderthal language revisited: not only us, Current Opinion in Behavioral Sciences, vol.21, pp.49-55.

61. Pinker, S. and Jackendoff, R.S. (2005), The faculty of language: what's special about it? Cognition, vol. 95, pp. 201-236.

62. Reznikova, Zh. (2007), Animal Intelligence: From Individual to Social Cognition, Cambridge University Press, New York, xiv, $472 \mathrm{p}$.

63. Gentner, T. Q., Fenn, K. M., Margoliash, D. and Nusbaum, H.C. (2006), Recursive syntactic pattern learning by songbirds, Nature, vol. 440, no. 7088, p. 1204-1207.

64. Zorina, Z. A. and Smirnova, A. A. (2006), What the "talking" monkeys talked about, Iazyki slavianskikh kul'tur Publ., Moscow, 424 p. (In Russian)

65. Ivanov, V. V. (2004), Linguistics of the Third Millennium: Questions for the Future, Iazyki slavianskikh kul'tur Publ., Moscow, 208 p. (In Russian)

66. Tattersall, I. (2004), What happened in the origin of human consciousness? The Anatomical Record Part B: The New Anatomist, vol.276, no. 1, pp. 19-26.

67. Grodzinsky, Y. and Nelken, I. (2014), The neural code that makes us human, Science, vol.343, no. 6174, pp. 978-979.

68. Johansson, S. (2015), Language abilities in Neanderthals, Annual Review of Linguistics, vol. 1, no. 1, pp.311-332.

69. Borinskaya, S. A. and Yankovsky, N. K. (2015), Combination of genetic and humanitarian (crosscultural) methods for the identification of human genes involved in the process of adaptation to evolutionary new environmental factors, Russian Journal of Genetics, vol.51, no. 4, pp. 397-407.

Received: September 27, 2019

Accepted: December 11, 2019

Author's information:

Tatiana V.Chernigovskaya — PhD (Biology), Professor; tatiana.chernigovskaya@gmail.com 


\section{Биология, среда и культура: от коммуникации животных к человеческому языку и познанию*}

\section{T. В. Черниговская}

Санкт-Петербургский государственный университет,

Российская Федерация, 199034, Санкт-Петербург, Университетская наб., 7-9

Для цитирования: Chernigovskaya T. V. Biology, environment, and culture: From animal communication to human language and cognition // Вестник Санкт-Петербургского университета. Философия и конфликтология. 2020. Т. 36. Вып. 1. С. 157-170. https://doi.org/10.21638/spbu17.2020.113

Противоречия в интерпретации данных различных наук, занимающихся антропогенезом и происхождением языка, невозможно преодолеть без комплексного междисциплинарного подхода. Важной задачей такой конвергенции является обеспечение комплементарности теоретических взглядов на проблему, что может быть достигнуто только при наличии общего языка ее описания. Человеческий язык - видоспецифичная способность мозга, дающая возможность не только выстраивать сложные коммуникационные сигналы, но и обеспечивать мышление. Язык характеризуется системой базисных универсальных правил, обусловленных, по всей видимости, свойствами самого мозга, с иерархически организованными уровнями - лексикон, грамматика (морфология, синтаксис, семантика и фонология) и прагматика. Многозначность свойство любого сложного информационного потока, независимо от модальностей восприятия - особенно ярко проявляется в языке. Именно благодаря произвольности и многозначности человеческий язык является не только средством коммуникации, но и важным инструментом познания. Механизмы, обеспечивающие язык и другие высшие функции, рассматриваются в рамках то локализиционистской, то холистической моделей. Парадигмы продолжают сосуществовать или чередоваться, и основные дискуссии происходят между сторонниками идеи модульной языковой способности человека, базирующейся на лежащей в основе всех языков врожденной универсальной грамматике, и приверженцами коннекционистской модели, согласно которой основой развития языка является обучение нейронной сети, что сближает взгляд на язык с подходами к изучению иных видов коммуникаций. Эволюция привела к обретению мозгом способности к вычислению, использованию рекурсивных правил и ментальных репрезентаций, создав основу для мышления и языка в человеческом смысле. Мы сталкиваемся с оппозицией школ, сводимой к схеме детерминизм/врожденность языка против модели научения на основе частотностей, прогноза и предсказуемости. Статья разбирает свойства когнитивных процессов, характерных для человека, и их возможные предпосылки на примере других биологических видов.

Ключевые слова: эволюция языка и сознания, системы коммуникации у животных, происхождение и эволюция человека, обработка информации в условиях неопределенности.

Статья поступила в редакцию 27 сентября 2019 г.; рекомендована в печать 11 декабря 2019 г.

Контактная информация:

Черниговская Татьяна Владимировна - д-р биол. наук, проф.; tatiana.chernigovskaya@gmail.com

* Исследование финансировалось РФФИ в соответствии с исследовательским проектом № 18-00-0646 (18-00-00640). 